\title{
O QUE É E PARA QUE SERVE A FUNDAMENTAÇÃO DA MORAL?
}

\author{
José Manuel Santos \\ Instituto de Filosofia Prática \\ Universidade da Beira Interior
}

\section{O questionamento}

Pode-se dizer que, pelo menos desde Kant, o discurso da filosofia moderna em matéria de ética gira em torno da questão da "fundamentação" da moral, ou, mais precisamente, do princípio universal da moralidade, da chamada "lei moral". Enquanto que, para os antigos, a tarefa da ética consistia fundamentalmente na especificação do "bem", e em particular, nomeadamente em Aristóteles, do "bem humano", os modernos vêem na fundamentação da "lei moral" a tarefa central, essencial e, para alguns autores, praticamente exclusiva da ética enquanto disciplina filosófica. Entretanto, mais recentemente, surgiam filósofos que questionam esta insistência na tarefa "fundacionalista" e apontam para os problemas e limites de uma teoria ética tão obsessivamente centrada na "fundamentação".

Convém começar por explicitar os níveis do questionamento moral que suscitaram a tarefa da fundamentação. Podemos distinguir três níveis deste questionamento. Num primeiro nível da reflexão moral, o nível mais primário e espontâneo, a questão moral mais ou menos implícita é, no fundo: Como me devo comportar na sociedade em que vivo? O que é o bem e o mal nesta sociedade? Com esta questão, o sujeito começa por procurar regras ou normas susceptíveis de orientar o seu agir no âmbito da interacção social. Nas sociedades mais tradicionais e/ou pré-modernas, estas normas provêm da tradição cultural ou da religião (que é um núcleo central dessa tradição).

Num segundo nível de questionamento, que também já pode ser considerado um primeiro nível do questionamento da ética, enquanto reflexão filosófica sobre a moral, coloca-se a questão de saber se uma dada

Philosophica, 37, Lisboa, 2011, pp. 129-152 
acção, e, portanto, a regra ou norma que ela actualiza (aquilo a que Kant chama "máxima”), seja qual for a sua proveniência (tradição, religião, doutrina filosófica, convenção social, etc.), é correcta ou não, válida ou não, "verdadeira" ou "falsa" no plano normativo. A resposta a esta pergunta requer a formulação de um princípio universal que permita subsumir e, assim, justificar toda e qualquer norma de natureza moral. Na deontologia moral kantiana a primeira tarefa da ética é a formulação deste princípio, o qual servirá de teste de validade susceptível de ser aplicado a toda e qualquer acção, ou, mais precisamente, a toda e qualquer "máxima” de acção.

A verdadeira questão da fundamentação só surge, na sequência da formulação do princípio universal, a um terceiro nivel de interrogação. Não se trata apenas de formular um princípio universal que possa servir de teste de verificação da "correcção" ou verdade moral, mas de "fundamentar" (begründen), um tal princípio. O problema central que põe esta fundamentação é que o que está aqui em causa não é apenas a sustentação lógica de um "princípio", mas, mais profundamente, a justificação de uma atitude, da atitude moral ou do "ponto de vista moral" enquanto tal. O que se trata de justificar é a moralidade. Esta questão de terceiro nível é, em última instância, a de saber "porque devo agir moralmente" ou "porque devo ser moral".

A filosofia moral deontológica responde a esta questão através de uma "fundamentação" que consiste, fundamentalmente, numa demonstração formal de não-contradição - não-contradição lógica ou semântica, em Kant, não-contradição "performativa”, em Karl-Otto Apel. No entanto, surgiram dúvidas sobre a intenção e o sentido de um tal projecto, sobre as suas motivações e funções. Não virá a "fundamentação" encobrir com a sua tecnicidade lógica e argumentativa um problema mais profundo?

É o que Nietzsche já desconfiava, nos finais do século XIX, quando escrevia:

"Em toda a 'ciência da moral' faltou ainda, até agora, por mais espantoso que isso possa parecer, o problema da própria moral: faltou a suspeita que podia haver aqui algo de problemático. Aquilo a que os filósofos chamaram a 'fundamentação da moral', e que exigiram que fosse levado a cabo, mais não é, bem vistas as coisas, que uma forma de crença na moral dominante, [...] um facto dentro da própria moralidade ou até mesmo, em última instância, uma espécie de desmentido que esta moral pudesse ser entendida como um problema."1

\footnotetext{
1 "In aller bisherigen 'Wissenschaft der Moral' fehlte, so wunderlich es klingen mag, noch das Problem der Moral selbst: es fehlte der Argwohn dafür, dass es hier etwas Problematisches gebe. Was die Philosophen 'Begründung der Moral' nannten und
} 
Não é preciso aceitar as consequências radicais que Nietzsche retirou desta interrogação para lhe dar razão em ter formulado o "problema”. Um século depois destas linhas terem sido escritas, houve filósofos como Ricœur ou Spaemann, manifestamente não susceptíveis de serem qualificados de "nietzscheanos", que retomaram e trabalharam este problema. Aquilo que a reflexão ética requer neste âmbito é, sem dúvida, qualquer coisa como uma fundamentação da fundamentação, algo que, um século depois de Nietzsche ter apontado para o "problema", a teoria ética viria de facto a desenvolver. Desta forma, a questão do terceiro nível, a questão profunda da fundamentação, "porquê ser moral?”, desdobra-se numa outra, paralela e meta-ética, sobre a própria razão de ser fundamentação: Porquê fundamentar a moral?

\section{O espectro das respostas à questão do porquê da fundamentação}

É possível que a resposta à questão de terceiro nível dependa, sem dúvida, como Nietzsche pensava, de uma "crença” ou "fé". Para Kierkegaard, como é sabido, a questão do terceiro nível não tem resposta, visto que, do seu ponto de vista, agir moralmente, ou seja entrar na esfera da moralidade, dependeria de uma "decisão absoluta" que não é passível de justificação, e ainda menos de "fundamentação" formal. Isto tem por consequência uma resposta fácil e óbvia à questão meta-ética paralela: "fundamentar a moral” é uma tarefa inútil e vã, para além de ser impossível. Convém, no entanto, ter também presentes na nossa análise as respostas positivas e "construtivas" às questões do terceiro nível. Na perspectiva destas respostas são amiúde invocados alguns objectivos por assim dizer funcionais, algumas "vantagens" da fundamentação da moral, que representam uma resposta clara à questão da utilidade da fundamentação. No âmbito das nossas relações com outrem, das interacções pessoais e sociais, em caso de falta de pontos de referência provenientes de uma tradição viva ou de uma religião, a "fundamentação" forneceria: a) uma base de orientação na esfera dessas relações, b) um conjunto de certezas racionais e, neste sentido, "verdadeiras" que serviriam para exigir a todos o respeito de direitos fundamentais de cada um, e c) convicções "fundamentadas" que permitiriam criticar crenças normativas sem fundamento e, portanto, "falsas”.

von sich forderten, war, im rechten Lichte gesehen, nur eine gelehrte Form des guten Glaubens an die herrschende Moral, [...] ein Thatbestand selbst innerhalb einer bestimmten Moralität, ja sogar, im letzten Grunde, eine Art Leugnung, dass diese Moral als Problem gefasst werden dürfe.” F. Nietzsche, Jenseits von Gut und Böse, KSA, Vol. V, p. 106. 
No extremo oposto do espectro das respostas às questões de nível três encontramos as respostas negativas, destrutivas ou "desconstrutivas" daqueles a que poderíamos chamar filósofos do soupçon, do Argwohn, da suspeição. Trata-se de filosofias que podemos subsumir na categoria do chamado não-cognitivismo - na qual poderíamos incluir o já referido Nietzsche. A corrente mais óbvia é o cepticismo ético, que afirma que as proposições normativas não são passíveis de verdade ou falsidade e que, a fortiori, princípios normativos de ordem moral não são passíveis de fundamentação racional. Pode-se invocar, em seguida, o emotivismo, que considera que os juízos normativos de ordem ética mais não são, em última análise, que expressões subjectivas de emoções ou sentimentos individuais. Um filósofo contemporâneo que, nesta discussão, ocupa uma posição original do lado dos filósofos do soupçon é Bernard Williams (1929-2003). Não recusando a necessidade de justificar o agir moral, este filósofo considera que as justificações que lhe podem ser dadas são demasiado plurais e complexas, não podendo, por conseguinte, encontrar uma expressão exacta e adequada na "fundamentação" de uma "lei moral” universal, que seria necessariamente reducionista e logicista.

\section{A fundamentação "absoluta"}

A discussão ética contemporânea está centrada no antagonismo entre cognitivismo e não cognitivismo. A filosofia moral moderna, cognitivista, vê o não cognitivismo, nas suas diversas variantes, como o grande desafio a que tem de dar resposta - e essa resposta é a "fundamentação absoluta" da norma moral universal. Se as normas não tiverem um fundamento absoluto, tal é o raciocínio, não é possível criticar pessoas ou acções numa perspectiva moral, ou seja, formular juízos morais válidos. Do lado oposto, os não cognitivistas consideram que, sendo a fundamentação implausível ou impossível, o acto de criticar moralmente pessoas ou acções tem um sentido estritamente funcional, de pura expressão de sentimentos ou de construção da subjectividade.

Acontece que o projecto da fundamentação "absoluta” da norma moral também tem os seus críticos para além dos não cognitivistas. Estes críticos recusam deixar-se encerrar na dicotomia moderna entre um fundacionalismo "absoluto" e um cepticismo ético igualmente absoluto. É verdade, como dizem os fundacionalistas "duros", que o cepticismo radical tem por consequência a ruína da teoria ética e o niilismo. No entanto, aquilo que uma crítica mais construtiva pode pôr em causa no projecto da fundamentação, sem cair no cepticismo, é a sua pretensão absolutista. Não se trata de rejeitar a necessidade de discutir e justificar as razões das nossas acções, ou as críticas que dirigimos a certos actos ou pessoas, mas 
apenas a pretensão de "demonstrar" uma alegada "necessidade absoluta" de um princípio universal.

Há autores que advertem para o facto de a filosofia moral moderna estar excessivamente centrada na questão da fundamentação e reduzir a ética a esta questão. Isto é problemático por vários motivos, entre os quais podemos referir dois. O primeiro é que apostar tudo numa só carta, na carta da fundamentação absoluta é perigoso. Se a demonstração fundacional falhar, esse falhanço deixa-nos completamente desprotegidos e desorientados do ponto de vista da justificação ética das nossas acções. O segundo é que é duvidoso que o dever moral, objecto da fundamentação, assente numa lei simples e não, como escreve Ernst Tugendhat, "num complexo de razões e motivos"2.

Antes de abordar as críticas há que compreender o que é a fundamentação "absoluta", aquilo a que Apel chama Letztbegründung (à letra fundamentação última). Não se trata, neste trabalho, de reconstruir as fundamentações absolutas mais paradigmáticas da Modernidade - nomeadamente a de Kant e a de Apel - cujo cujo conhecimento é pressuposto, mas apenas tentar caracterizar os traços marcantes, os pressupostos e o "espírito" do procedimento fundacionalista.

A ideia da fundamentação absoluta remete para um modelo de ética que pode ser caracterizado a partir de cinco tópicos: regra, procedimento, racionalidade formal, universalidade do princípio, possibilidade da crítica normativa prática (ou seja, de acções ou pessoas). Estes tópicos podem ser sucintamente descritos como segue.

1) Regra. O primeiro pressuposto da fundamentação é a possibilidade de tradução da moralidade das acções num conjunto de regras explicitas cuja validade seja susceptível de ser demonstrada. Trata-se de um modelo de ética em que vigora o primado absoluto da "razão discursiva".

2) Procedimento. A ética das regras desenvolve procedimentos argumentativos, destinados a mostrar a validade moral de qualquer regra de comportamento, e, sobretudo, a demonstrar a validade do princípio universal, que serve para "testar" toda e qualquer norma de natureza moral.

Neste contexto, alguns teóricos da ética estabelecem uma oposição entre éticas "procedimentais", de um lado, e éticas substanciais, do outro. Estas últimas não estão centradas em sistemas de regras e na sua fundamentação mas numa definição do conteúdo do "bem" humano, a qual representa, em última análise, uma hermenêutica da conditio humana.

3) Racionalidade formal. O cerne da argumentação que constitui a

2 Tugendhat, 1994, 28. 
fundamentação do princípio universal reside na demonstração de uma "necessidade” lógica ou transcendental, ou seja de uma não-contradição interna à própria racionalidade - ou à "Razão" no sentido de Kant. Este tipo de racionalidade veicula o conjunto dos ideais "científicos" cartesianos da ciência moderna: exactidão, rigor, não contradição, clareza (univocidade semântica dos termos), etc.

4) Universalidade e 5) crítica. A fundamentação é a demonstração da validade universal de princípios morais universais. Tendo em conta a universalidade, não há nenhum comportamento, atitude, costume, tradição, etc. que possa pretender escapar a uma "crítica" na perspectiva da moral.

Estes pressupostos da ética da fundamentação (regras, procedimentos, recionalidade formal, universalidade, e crítica) acarretam, para a teoria ética, uma exigência epistemológica de carácter lógico-matemático sem paralelo com o que existia nas éticas antigas. A moderna filosofia moral deontológica pretende desmentir em absoluto a ideia de Aristóteles de que não se pode exigir em ética o mesmo rigor, a mesma akribeia, que em matemática. ${ }^{3}$ Dois factores devem ser referidos na origem desta concepção da ética como "ciência rigorosa”: o espírito cartesiano da ciência dos modernos e, sobretudo, a teologia moral - disciplina que, pela sua metodologia e sistematicidade, já pretendia ao maior rigor "científico". ${ }_{4}$

O que significa, para a ética, a busca de uma fundamentação "última" ou "absoluta"?

Na ética antiga havia discussões sobre a concepção e o conteúdo do "bem”, mas era consensual que a intuição do "bem”, ou, como dizia Sócrates, o "saber" do bem, fornecia, simultaneamente, as razões (da razão) e as motivações (da vontade) da boa acção. Não era necessária, da parte do ético, uma complicada operação de "fundamentação". Para o detentor desse "saber", o bem seria evidente.

Kant começa por democratizar o "saber” ético, reduzindo-o à norma-

\footnotetext{
${ }^{3}$ EN, 1094b 25sq.

${ }^{4}$ Sobre a dependência da filosofia moral de Kant da teologia moral de Christian August Crusius (1715-1775), o mais eminente expoente da teologia moral protestante do século XVIII, ver Krämer, 1992, 11: "Die imperativistische Energie der Sollensethik hat Kant ersichtlich der Moraltheologie entnommen, nicht ohne sie in charakteristischer Weise zu säkularisieren und profanethisch umzudeuten. Dies zeigt der Vergleich mit Ch. A. Crusius, dem Kant oft bis ins Detail folgt, nur dass die Theonomie durch die Autonomie des Vernunftwillens ersetzt und damit die Gewichte der Moraltheologie umkehrt: War die Vernunft bei Crusius Stellvertreter Gottes, so rückt sie bei Kant zum Äquivalent Gottes auf, der seinerseits zu ihrem Satelliten herabgestuft wird.”
} 
tividade moral e sustentando que a consciência moral das pessoas mais simples é infalível a distinguir o bem do mal. Todavia, isso não o impediu de nos ter deixado a fundamentação da moral tecnicamente mais sofisticada e engenhosa da história da ética. No contexto moderno, tudo se passa como se o filósofo fosse afligido por uma dúvida radical, uma inquietante insegurança sobre a bondade e a racionalidade da "lei moral". Há aqui, no ponto de origem da filosofia prática moderna, uma dúvida metódica absoluta paralela à dúvida cartesiana no campo da filosofia teórica.

Quais os motivos desta insegurança e desta dúvida? Uma resposta simples consistiria em dizer que a dúvida prática vem do facto de a ideia de "lei moral" provir de um regime anterior, da moral religiosa, no qual essa lei é revelada aos homens sob a forma de "mandamentos de Deus". O filósofo moderno teria o dever de proceder como se não tivesse havido revelação - etsi non daretur Deus ${ }^{5}$. Todavia, a independência substancial da filosofia moral em relação à revelação ou à existência de Deus não impede a retoma da questão e da estrutura argumentativa que lhe é inerente. Neste sentido, é preciso ir mais longe na análise. A nossa tese é que os motivos da dúvida moral radical têm que ver com o próprio tipo da racionalidade moderna enquanto herdeira de um tipo de questionamento. O exercício dessa racionalidade tem consequências no contexto da acção, e, portanto, no campo da ética.

O traço distintivo da racionalidade moderna - sobretudo no terreno da prática - é um hiato entre a razão e a ordem natural. ${ }^{6} \mathrm{Na}$ ética aristotélica, os objectivos e fins da acção humana são pensados no âmbito de uma ordem natural. Agir racionalmente significa agir em harmonia com a ordem natural em que se inserem as acções dos seres humanos. É, assim, compreensível que para Aristóteles a inteligência prudencial (a phronêsis, o cerne das virtude dianoéticas) seja um factor importante do bem agir. Ao invés, do ponto de vista da filosofia moral deontológica, agir moralmente bem não necessita de grande inteligência, mas apenas de uma "boa vontade". A racionalidade aristotélica obriga a pensar o bem tendo em conta uma ordem concreta, situações previamente dadas, ou seja a conditio humana, em geral, e as condicionantes particulares de cada agente e cada acção. É uma racionalidade do concreto e da sua complexidade.

A razão moderna, que pretende ser a-teleológica e a-teológica, proíbe-se todo e qualquer pressuposto de uma "ordem" pré-estabelecida. Nenhuma ordem natural das coisas pode ser pressuposta e servir de orientação. Por conseguinte, enquanto racionalidade do puro agir, a razão prática moderna tem de encontrar em si própria a sua própria lei. A fundamenta-

${ }^{5}$ Argumento utilizado por Grotius para marcar a independência do direito natural moderno em relação à teologia.

${ }^{6} \mathrm{O}$ desenvolvimento que segue apoia-se em parte em Taylor, 1993. 
ção absoluta é a demonstração da necessidade da lei moral a partir da estrutura "interna" da racionalidade, da "autonomia" da razão. Na ausência de uma ordem natural ou da vontade de Deus, a fundamentação é, como escreve Ricœur, "auto-fundação": demonstração da não contradição interna da racionalidade em acto.

Veremos que esta auto-referência absoluta da racionalidade tem por efeitos uma descontextualização e uma desmundanização do princípio moral que vai colocar problemas ao nível da sua aplicação concreta em situação. Para já, aquilo que se trata de mostrar são alguns aspectos da "genealogia" da ideia da fundamentação. Um aspecto-chave da racionalidade moderna passa por uma radicalização do conceito de liberdade. É este conceito que permite aprofundar o hiato entre ordem natural e ordem da razão. No contexto da filosofia antiga, nomeadamente aristotélica, o ser humano já é responsável pelos seus próprios actos ${ }^{7}$, ou seja, dito de maneira simples, é livre. A "liberdade" insere-se naturalmente num mundo em que a ordem natural não exclui a contingência. O facto da contingência é causa e condição da liberdade. Liberdade e contingência são condições de possibilidade de realização de uma vida humana considerada "boa”. No plano político, o "homem livre" é aquele que não está sujeito a outros, é, simplesmente, o que não é escravo e, em consequência, participa nas decisões colectivas da polis - actualizando uma liberdade a que, hoje, se costuma chamar "positiva”. Já a "liberdade” moderna é muitíssimo mais do que a simples condição de possibilidade de realização do bem positivo. A "liberdade" humana é interpretada pelos modernos, e paradigmaticamente por Kant, como um corte radical com a ordem da natureza, como causa excepcional e "milagrosa" que se vem inserir na cadeia da causalidade "mecânica" e determinística da natureza. Esta liberdade radical faz das acções humanas acontecimentos supra-naturais, e faz do ser humano, como diz Kant, um "cidadão de dois mundos": mundo sensível e "mundo inteligível".

O filósofo Charles Taylor leva a cabo uma "genealogia" deste conceito radical de liberdade, mostrando, em simultâneo, a sua importância para a compreensão da racionalidade moderna e para a génese e motivação das éticas procedimentais fundacionalistas. ${ }^{8}$ No que toca à "genealogia”, ele mostra a origem da moderna liberdade radical na querela tardo-medieval do nominalismo e do voluntarismo divino. A liberdade absoluta da "vontade" kantiana em relação à natureza imita a liberdade da potentia absoluta do Criador em relação a qualquer ordem pré-existente. Esta origem teológico-metafísica da liberdade humana não é alheia aos

\footnotetext{
${ }^{7}$ Aristóteles, EN, $1112 \mathrm{~b} 31$; $1113 \mathrm{~b} 18$.

8 Taylor, 1993.
} 
sérios problemas que coloca a liberdade radical à fundamentação da moral. O principal é que se trata, como o próprio Kant admite, de um conceito especulativo e metafísico, ou seja de algo impossível de provar. Isto constitui um problema para uma fundamentação dependente deste conceito. Por este motivo, como veremos a seguir, um dos mais importantes herdeiros de Kant em matéria de fundamentação da moral, Karl-Otto Apel, vai, muito habilmente, afastar da sua teoria ética este conceito radical e metafísico de liberdade. ${ }^{9}$

Uma última nota relativamente a Kant. A novidade radical da ética de Kant poderá ser posta em evidência se a compararmos com a ética do estoicismo - a qual, como é sabido, também se centra na "razão" e pode-se apresentar sob a forma de uma ética do dever. À primeira vista a máxima estóica secundum rationem vivere tem um "ar" kantiano avant la lettre. Trata-se, no entanto, de uma aparência. A razão estóica é natural e cosmológica. A máxima secundum rationem vivere longe de contradizer a outra máxima capital do estoicismo, secundum naturam vivere, é homóloga a esta. A razão estóica é a da natureza. Para Kant, agir de acordo com a "razão prática” é precisamente não agir segundo a natureza. No seu uso prático a razão kantiana é literalmente meta-física, está para além da physis. A ética estóica, apesar de ter desenvolvido um sistema de "deveres", continua a ser uma ética do "bem" substancial, da vida boa no âmbito do cosmos e da natureza, e não um racionalismo formalista da não contradição imanente ao agir "racional" numa comunidade de "seres racionais" sem mundo e sem vida mundana.

\section{Problemas internos da fundamentação absoluta}

A fundamentação formal e absoluta começa por apresentar dois tipos de problemas. Os do primeiro tipo dizem respeito ao carácter contra-intuitivo de um princípio moral puramente formal - o qual impede de ter em conta conteúdos substanciais do bem e as consequências do agir. $\mathrm{Na}$ medida em que este tipo de ética estabelece uma equação entre moralidade e racionalidade, o princípio moral acaba por se tornar num simples teste de consistência ou não-contradição lógica. Desta feita, como Hegel já notava, faltam a uma tal ética princípios substanciais operativos, razões do agir assentes numa racionalidade substancial. Acresce a isto, como problema suplementar, a falta de motivação de um agente obrigado a abstrair de todos os seus interesses, por mais legítimos que sejam, para assumir o "ponto de vista moral", ou seja a perspectiva de um desinteressado observador do mundo, um kosmotheoros, situado fora do mundo e

${ }^{9}$ Apel, 1996, 331. 
da vida. Tal seria o preço a pagar por uma fundamentação que exige uma necessidade formal absoluta de carácter lógico ou transcendental.

Mais recentemente surgiram filósofos - como Charles Taylor ou Paul Ricœur - que, não pondo em dúvida uma certa utilidade e pertinência da deontologia fundacionalista como teoria ética, exigem um complemento substancial para a completar. Voltarei a esta questão.

Os problemas do segundo tipo decorrem dos pressupostos "metafísicos" do conceito kantiano de "liberdade", que sustentam o conceito formal de "razão" e o contaminam. É nesta perspectiva que mesmo um filósofo como Karl-Otto Apel, que tenta levar a bem por novos meios a tarefa de uma fundamentação transcendental da moral, critica a fundamentação kantiana. O seu argumento é que a lei moral kantiana assentaria, fundamentalmente, na consistência lógica, ou seja na não contradição, do pensamento de um sujeito pensante que é um cogito "solipsista" e "monológico". Para universalizar a lei, este cogito ético é obrigado a postular a existência de uma pluralidade de "seres racionais" que constituem, no seu conjunto, um "reino dos fins" e representam um "mundo intelígível”. Para Apel este pressuposto seria metafisico ${ }^{10}$ e, portanto, não transcendental. Além disso, de acordo com o próprio Kant, a liberdade, que constitui o traço distintivo essencial dos seres racionais e morais, só pode ser "pensada" mas nunca "conhecida" ou "provada", constituindo, assim, segundo Apel, uma outra hipoteca metafísica da fundamentação do filósofo de Königsberg. ${ }^{11}$ Para superar estas fraquezas, Apel, que também pretende levar a cabo uma fundamentação transcendental, vai transferir a base dessa fundamentação da razão monológica de um cogito reflexivo e solipsista, que ela teria em Kant, para uma "razão dialógica" de um jogo argumentativo - de um Sprachspiel, no sentido de Wittgenstein - no qual está assegurada à partida uma pluralidade de sujeitos, que são, simultaneamente, agentes da praxis, sujeitos éticos e jogadores do Sprachspiel da “argumentação racional”. A não-contradição ou necessidade puramente semântica do formalismo kantiano cederia, assim, o lugar a uma não-contradição performativa inerente à racionalidade pragmática do Sprachspiel argumentativo. A racionalidade pragmática é a que regula os actos de linguagem, speech acts (Austin), de seres que usam a linguagem para organizarem no mundo as suas vidas no âmbito da comunidade de seres que partilham esse uso.

A teoria ética de Apel apresenta dois postulados à primeira vista plausíveis. O primeiro é que os seres humanos são seres interessados em cooperar, ou seja, seres que se empenham espontaneamente em acções

\footnotetext{
10 Apel, 1996, 330.
}

11 Apel, 1996, 331. 
cooperativas. O segundo é que o uso da linguagem, o agir comunicacional (Habermas), constitui o núcleo e o fundamento da praxis cooperativa. Falar já é um agir. Nesta perspectiva, parece plausível que a lógica da "racionalidade comunicacional", que é racionalidade pragmática, seja mais adequada do que a simples racionalidade "semântica" para uma demonstração da equação de equivalência entre racionalidade e moralidade. No âmago da fundamentação apeliana - que se pretende absoluta e última, ou seja Letztbegründung - está a figura da contradição performativa. Trata-se da contradição que ocorre sempre que um sujeito formula um juízo cujo conteúdo proposicional contradiz as condições de possibilidade do seu próprio acto de formulação ou enunciação. Um caso simples de uma manifesta contradição performativa é, por exemplo, o juízo “eu não existo". A existência de um locutor é obviamente necessária ao acto de julgar (acto "ilocutório") ou de enunciar um juízo (acto "locutório"). A tese central da ética da discussão é que, no âmbito do Sprachspiel da "argumentação racional”, existem pressupostos universais e necessários que já seriam, em si, de ordem ética ou moral. A fundamentação de leis morais universais seria um caso importante deste género de discussão ou Sprachspiel. Do ponto de vista ético, os pressupostos mais relevantes desta discussão dizem respeito, em particular, à igualdade de direitos de todos os parceiros do Sprachspiel e à vontade comum a todos de resolver conflitos normativos pela via da argumentação racional e sem recurso à violência. ${ }^{12}$ "Violência", para Apel, não é apenas violência física primária. Este conceito também compreende o recurso a técnicas de retórica, de persuasão ou de sedução. A tese de Apel afirma que a negação destes pressupostos por um argumentador céptico que negasse a sua validade constituiria uma contradição performativa, na medida em que esse céptico, enquanto argumentador, ou seja, jogador do Sprachspiel da argumentação racional, já teria aceite os pressupostos da "igualdade de direitos" e da vontade de resolver diferendos apenas pela força da argumentação. Negar a validade dos princípios da moralidade seria, assim, negar os pressupostos do "jogo" argumentativo que o próprio céptico pretende estar a jogar. $\mathrm{O}$ cepticismo ético colocaria o céptico não só fora da dimensão da moralidade, mas também fora do campo da racionalidade. A persistência na tese céptica seria um comportamento irracional.

A fundamentação de Apel reside, no essencial, num argumento ad absurdum: não se trata de demonstrar a tese por dedução axiomática a partir de princípios gerais, mas de mostrar uma contradição performativa do adversário que provaria a "necessidade absoluta" do princípio universal defendido em tese. Num plano puramente lógico, o argumento fundacionalista ad absurdum pretende escapar ao modelo da demonstração

12 Apel, 1996, 333. 
axiomática, e, desta forma, ao paradoxo conhecido como trilema de Münchhausen ${ }^{13}$. A escapatória, contudo, foi rejeitada por Hans Albert ${ }^{14}$, que considera que o argumento de Apel não escapa de modo algum ao trilema do barão das mentiras. Dito isto, como no presente trabalho nos colocamos no terreno da teoria ética, não aprofundaremos esta crítica lógica e epistemológica, preferindo apontar para problemas de filosofia prática colocados pela fundamentação de Apel, e que passamos a formular de maneira sumária e programática. Os problemas nucleares são dois.

$1^{\circ}$ ) O argumento de Apel constitui uma forma drástica de reducionismo. Há aqui uma dupla redução: a redução da vida e da praxis, com toda a sua complexidade (não só linguística), aos "actos de linguagem”, e, em seguida, uma redução das múltiplas formas de "jogos de linguagem” a um único Sprachspiel chamado "argumentação racional”. Acontece que o filósofo que está na origem da pragmática da linguagem, Wittgenstein, considerava que os usos da linguagem permitem uma pluralidade aberta de Sprachspiele que correspondem a diferentes "formas de vida”.

$2^{\circ}$ ) A identificação reducionista entre uma "argumentação racional" e formal e a vida tout court leva à não distinção, problema subsequente, entre sujeito argumentador e sujeito ético (agente da praxis). Se fizermos esta distinção, que se impõe, não é contraditório ou "irracional” admitirmos alguém como sujeito argumentador numa discussão argumentativa e conceder-lhe igualdade de direitos no âmbito do "jogo" argumentativo - e não o reconhecer como sujeito ético, como "pessoa”, para além desse "jogo".

As "condições ideais" da discussão racional - as regras do "jogo" argumentativo - não podem ser consideradas já em si normas "éticas” ou morais. Jürgen Habermas reconheceu esta fraqueza da ética de Apel e,

${ }^{13}$ Em que consiste o trilema de Münchhausen? Toda a tentativa de fundamentação "absoluta" de uma tese ou proposição desembocaria neste trilema, que deve o seu nome a um lendário barão alemão, mentiroso compulsivo e dotado de uma esfusiante imaginação. O proponente tem de escolher entre três opções, sendo todas elas vias de fracasso. Terá de optar entre: "1. einem infiniten Regreß, der durch die Notwendigkeit gegeben erscheint, in der Suche nach Gründen immer weiter zurückzugehen, der aber praktisch nicht durchzuführen ist und daher keine sichere Grundlage liefert; 2. einem logischen Zirkel in der Deduktion, der dadurch entsteht, daß man in Begründungsverfahren auf Aussagen zurückgreift, die vorher schon als begründungsbedürftig aufgetreten waren, und der ebenfalls zu keiner sicheren Grundlage führt; und schließlich: 3. einem Abbruch des Verfahrens an einem bestimmten Punkt, der zwar prinzipiell durchführbar erscheint, aber eine willkürliche Suspendierung des Prinzips der zureichenden Begründung involvieren würde.” Albert, 1992, 15.

14 Cf. Albert, 1982; Albert, 1992, 274. 
por isso, desistiu da ideia de uma pragmática transcendental como base da ética da discussão em proveito de uma "pragmática universal". Na pragmática universal, a fundamentação deixa de ser "absoluta”. Para compensar, Habermas, acentua o carácter procedimental da discussão e torna mais operativa a ideia do "consenso". Mas neste caso, como notaram alguns críticos ${ }^{15}$, surge outro problema: abandona-se a esfera da moralidade e passa-se à da política.

$3^{\circ}$ ) Apel postula que a "argumentação racional”, e, nesta, mais precisamente, a "força ilocutória" dos actos de linguagem, garantiria respostas únicas e "necessárias" a todos os "problemas de validade moral". A exorbitância desta pretensão salta particularmente à vista se pensarmos em algumas questões controversas de ética aplicada como a da interrupção voluntária de gravidez ou da eutanásia. Poderia, nestes casos, a "força ilocutória" do "melhor argumento" resolver a questão de fundo e gerar uma resposta única? A resolução destas questões depende muito daquilo que se considera ou se crê ser a "vida" ou a "dignidade" do ser humano. É, no mínimo, problemático pensar que possa existir, neste domínio, um procedimento de "argumentação racional" de tal forma mecânico que produziria necessariamente uma e apenas uma solução dos problemas que seria a única "racional".

\section{5. Ética versus moral}

Estas dificuldades levantadas pela fundamentação absoluta da norma moral parecem dar alguma razão a A. MacIntyre, quando este considera que o "projecto iluminista de fundamentação da moral" é um "fracasso". ${ }^{16}$ Este fracasso seria a principal causa do sucesso de tendências como o cepticismo ético, o relativismo ou o emotivismo que marcam em profundidade a cultura da nossa época. Reagindo a esta situação, houve filósofos - como Philippa Foot e o próprio MacIntyre - que tentaram reactualizar éticas teleológicas do "bem" ou da "vida boa". Mais recentemente, contudo, surgiram em teoria ética propostas - como as de Paul Ricœur ou de Robert Spaemann - que ultrapassam a alternativa simples entre deontologia e teleologia e tentam estabelecer pontes ou mostrar uma certa complementaridade entre estes dois tipos de ética. Além disso, estes filósofos recusam a chantagem teórico-moral de alguns teóricos da deontologia, como Apel, que consideram que a única alternativa à fundamentação absoluta é o relativismo ou o amoralismo. Um dos filósofos que vai no sentido da “complementaridade” é Charles Taylor. Para ele as dificuldades da fun-

15 Como, por exemplo, Spaemann, 1998, 179.

${ }^{16}$ MacIntyre, 1985, 51. 
damentação absoluta não implicam a renúncia pura e simples à deontologia moral; apenas apontam para a necessidade de uma reformulação da justificação ética das normas em termos substanciais - e não apenas formais ou procedimentais. Para Taylor, as éticas deontológicas e procedimentais só adquirem coerência interna se explicitarem uma ideia do "bem" e clarificarem os seus "motivos" mais profundos. ${ }^{17}$

Isto leva-nos ao tema da oposição - muito discutida na teoria ética contemporânea - entre "ética" e "moral”. Filósofos como P. Ricœur ou B. Williams constroem uma oposição entre os conceitos de "ética" e "moral", no sentido em que entendem por "ética" uma ética da "vida boa" ou do bem (cujo paradigma são as éticas antigas) e por "moral" uma teoria ética de tipo puramente deontológico, assente na expressão de um "dever", na formulação de uma regra ou lei moral, e na sua fundamentação. A ideia da fundamentação absoluta surge, antes de mais, como uma fundamentação da moral - ou mais precisamente da "lei moral" - tem que ver com a estrutura da "moral". A moral assenta na formulação de "regras" e o esforço teórico vai no sentido da "justificação" ou "demonstração" da "validade" destas regras. No contexto da "ética", o esforço teórico não se aplica à formulação de regras explicitas e, portanto, à fundamentação destas, mas a uma hermenêutica do "bem humano". Do ponto de vista da moral as grandes questões da ética parecem ser a expressão de um interesse egoísta, e portanto, ilegítimas. São questões que dizem respeito à orientação da vida na perspectiva da primeira pessoa, do sujeito da acção. Inversamente, do ponto de vista da ética, a problemática moral aparece como um redução ilegítima da esfera ética. As filosofias que tentam articular deontologia e teleologia procuram obviar aos inconvenientes de ambas. A questão que nos interessa é a de saber como se coloca e se resolve, nestas filosofias da mediação entre ética e moral, o problema da fundamentação da moral.

Entre os projectos éticos que tentam articular ética e moral, teleologia e deontologia, encontramos os de Paul Ricœur e Robert Spaemann. Apesar de considerar que há uma certa complementaridade entre as duas perspectivas, Ricœur defende a tese de um "primado da ética sobre a moral”18. É afirmado um primado da "perspectiva ética”, que consiste em "visar a vida boa", sobre a perspectiva da moral, que consiste em visar a norma. Isto não impede este autor de considerar a moral como uma perspectiva importante e a ter em conta em teoria ética. Ora, se há um primado da ética, mas a perspectiva moral não é rejeitada, resta saber para que serve a moral. Na tentativa para mediar entre as duas perspectivas,

\footnotetext{
17 Taylor, 1993, 349.

18 Ricœur, 1990, 202. Sublinhado por nós.
} 
Ricœur começa por fazer uma leitura muito hábil da Ética a Nicómaco destinada a mostrar neste texto a presença de elementos morais, ou seja a desarmar as críticas recorrentes de um alegado "egoísmo" ou "amoralismo" que alguns vêem na ética aristotélica da eudaimonia. Numa leitura da teoria da amizade, Ricœur interpreta a philia aristotélica como uma "solicitude" em que o respeito por si e o respeito pelo outro são indissociáveis - estando assim afastada a interpretação da philautia como amour propre (no sentido clássico deste conceito), ou seja como puro egoísmo.

A solicitude já é uma relação ao outro tendencialmente moral, muito próxima da "benevolência" (em alemão Wohlwollen), que é, literalmente, um "querer o bem" do outro, um conceito que, no projecto ético de Spaemann, é o conceito central da moral. A diferença entre Ricœur e Spaemann está em que, enquanto o filósofo francês tenta estabelecer uma continuidade entre philia e solicitude, o filósofo alemão aprofunda a distância entre philia e Wohlwollen (benevolência), ou seja, entre uma ética da felicidade, essencialmente grega, e uma "moral" do dever, essencialmente cristã, tornando-a intransponível.

Perante esta interpretação da philia como "solicitude", que encontramos em Ricœur, a questão que se põe é a seguinte. Se, na perspectiva ética ou teleológica, já é tematizada e valorizada uma relação com outrem marcada pelo respeito, o que acrescenta a moralidade? Em termos simples: Porquê a moral? A resposta do filósofo francês é que a moral foi concebida para responder ao desafio que representa a existência do mal no sentido do mal que o ser humano pode fazer ao seu semelhante. Da existência do "mal decorre a necessidade, para a ética [teleológica] de assumir as formas da moral [deontológica]". "Porque o mal existe, a intenção [teleológica] da vida boa deve assumir a prova da obrigação moral". A função da moral é, pois, de "replicar à violência". "A todas as figuras do mal", da violência arbitrária ou gratuita, "responde o não da moral" 19 .

Dir-se-ia que Ricœur faz sua a resposta que Kant dá à mesma questão - porquê a moral? - no famoso ensaio sobre o "mal radical”. Pode-se, no entanto, observar uma diferença importante. Em Ricœur não encontramos os pressupostos e o pathos teológico-protestante que marcam o texto kantiano. O mal é uma triste realidade, ou, como defendeu Arendt, uma triste "banalidade". Aristóteles já tem, na sua lista das virtudes a nemesis, uma virtude à qual, do ponto de vista moderno, seríamos tentados a qualificar de "moral”. A nemesis já é o "não" visceral à violência que Ricœur atribui à "moral”; é a reacção virtuosa natural de indignação perante o espectáculo da injustiça e do mal.

Mas voltemos à nossa questão central, a da fundamentação, agora no

${ }^{19}$ Ricœur, 1990, 254. 
contexto do projecto ético de Ricœur. É de certo modo natural, na perspectiva deste autor, que uma exigência de "fundamentação" decorra naturalmente do ponto de vista da moral. Com efeito, o que está na mira deste ponto de vista é o "mal", a ameaça da violência interpessoal. A norma exprime a vontade que não seja aquilo que não deve ser, a vontade que a realidade do mal não aconteça. É compreensível que a filosofia moral se dê por tarefa demonstrar a "necessidade" universal do imperativo moral que o mal não seja.

Acontece, porém, que Ricœur não aconselha à filosofia da moral a via real da "fundamentação absoluta". Ele próprio afirma "renunciar à ideia da fundamentação última" ${ }^{20}$. E porquê? Porque este tipo de fundamentação dá-se a ilusão de "fundar" a moral através da simples demonstração de uma não contradição lógica colocada no colocada no fulcro do princípio moral e identificada com ele. Para Ricœur esta identificação é um erro. Numa crítica que visa tanto a fundamentação de Kant como a de Apel, Ricœur censura "a redução da prova de universalização" a uma simples "não-contradição" 21 interna. Dito de outro modo: aquilo que é moralmente válido não tem a sua sustentação no simples facto de ser "racional”, no sentido simples do não contraditório.

Que alternativa propõe Ricœur? Em vez da fundamentação, entendida como procedimento puramente demonstrativo, ele desenvolve um procedimento hermenêutico destinado a mostrar o conteúdo vivencial positivo que dá sentido ao conteúdo da norma e a legitima na função de teste ou prova. No essencial, a norma moral exprime a obrigação do respeito pelas pessoas, ou seja, dito de maneira inversa: proíbe a instrumentalização do ser humano. É isto que é exprimido por Kant na segunda fórmula do imperativo categórico ${ }^{22}$. Para Ricœur esta norma do respeito, pelo outro e por si mesmo, só ganha um sentido positivo se for "ligada à estrutura dialogal da intenção ética, ou seja à solicitude"23. Sendo a interacção cooperativa a forma de vida natural dos humanos, a chamada "regra de ouro" constituiria, para,œ ao nível da experiência intersubjectiva e da praxis, o elemento de mediação entre a solicitude (que procede da philia) e a norma moral imperativa do formalismo deontológico. Dito de outro modo: a norma moral

\footnotetext{
20 Ricœur, 1990, 329.

21 “Cette réduction de l'épreuve d'universalisation à la non-contradiction donne une idée extraordinairement pauvre de la cohérence à quoi peut prétendre un système de morale”. Ricœur, 1990, 321. Esta crítica é dirigida a Kant. Apel é criticado no mesmo sentido na p. 328.

22 "Age de tal maneira que uses a humanidade, tanto na tua pessoa como na pessoa de qualquer outro, sempre e simultaneamente como fim e nunca simplesmente como meio”. [Trad. de Paulo Quintela]. Kant, 1965 [1785], 52 [A67].

23 Ricœur, 1990, 254.
} 
enunciada formalmente na segunda fórmula do imperativo kantiano é uma "formalização da regra de ouro"24. Mas para que serve esta "formalização"? Ricœur começa por recusar a crítica contundente que Hegel faz do formalismo moral kantiano, acusando-o de ser "tautológico" e "vazio". Para Ricœur, a norma formal tem uma função ética importante. Ela serve para "pôr à prova da norma" deontológica o "visar da ética" (a visée éthi$q u e)^{25}$ teleológica. "A moral da obrigação”, escreve Ricœur, tem a função de "pôr à prova as ilusões sobre nós mesmos e o sentido de inclinações que obscurecem o visar [la visée] da vida boa”26.

Destas análises de Ricœur podemos retirar algumas conclusões. A primeira é que a aspiração à vida boa, a perspectiva teleológica, é indispensável como fundo da moralidade e é aquilo que dá sentido à norma moral formal. É a teleologia, a perspectiva teleológica, que dá um fundamento à deontologia. Esta tese está próxima da de Charles Taylor, segundo a qual uma ética das regras ou do procedimento só é coerente se for completada por uma ética do "bem". A segunda é que a norma formal é um simples instrumento "técnico" para afinar e precisar uma visée ética original fundamentalmente teleológica. Resta saber porque se inventou este instrumento. Em Soi-même comme un autre, Ricœur não responde directamente a esta pergunta. Uma resposta que se pode avançar, e que arriscamos por nossa conta, é que tudo se passa como se o homem moderno não dispusesse da superior capacidade de discernimento do bem que possuía o phronimos de Aristóteles, e necessitasse de um instrumento por assim dizer técnico de orientação.

Mas, como todas as técnicas, este instrumento não é perfeito. Por este motivo, Ricœur é obrigado a chamar a atenção para um outro problema da deontologia moral que não se coloca a montante - como é o caso da fundamentação da norma universal - mas, por assim dizer, a jusante, ao nível do uso do instrumento, ou seja, ao nível da aplicação da norma universal, no contexto da acção concreta ${ }^{27}$, ou seja daquilo a que hoje se chama ética aplicada. A aplicação da regra universal a casos particulares é frequentemente problemática e pode conduzir, em certos casos, a dilemas trágicos. Ricœur dá como exemplo o caso de um médico que tem de optar entre revelar a um doente a verdade sobre o estado muito grave em que ele se encontra ou mentir-lhe ${ }^{28}$. No primeiro caso, cumpre a letra da

\footnotetext{
24 Ricœur, 1990, 264

25 Ricœur, 1990, 237.

26 Ricœur, 1990, 279.

27 Ricœur, 1990, 329.

28 Ricœur, 1990, 313-314. As questões da eutanásia a da interrupção voluntária da gravidez também constituem problemas sérios e dramáticos que uma simples aplicação mecânica da norma universal é incapaz de resolver. Estes dois exemplos são
} 
norma universal mas corre o risco de fazer violência a um ser fragilizado. Acontece, porém, que este comportamento significa não respeitar a própria pessoa. Neste caso, como noutros, Ricœur considera que o dilema que se coloca entre respeitar a regra ou respeitar a pessoa - dilema típico da deontologia - só pode ser resolvido com recurso à perspectiva da "visée éthique", da intenção teleológica. Só nesta perspectiva se pode intuir a necessidade de fazer uma "excepção" à regra, a qual é legitimada pelo facto de ser a favor do outro, feita por respeito por ele, e não por interesse próprio e egoísta. No fundo, esta resolução de conflitos causados pela aplicação da regra deontológica conduz à adopção de algo como uma ética da phronêsis. A phronêsis é a interiorização viva do bem enquanto capacidade de julgar e agir em situação.

Uma vez chegados aqui, acreditamos possuir duas conclusões provisórias. A primeira é negativa: renunciar à "fundamentação absoluta" ou "última” da ética deontológica, seja ela transcendental ou pragmática. A segunda é positiva: aceitar a sugestão de Ricœur de conceber uma "sabedoria prática" acima da moral, a qual, não pondo em causa a moral, nos mostra que, sobretudo em casos de conflito na aplicação da norma moral em situação, pode ser necessário fazer excepções à regra formal da moral. Nestes casos justifica-se uma excepção, desde que não seja a meu favor mas por respeito pelo outro.

Chegados aqui, a tarefa da teoria ética seria responder à questão “porquê respeitar o outro?” A função da ética seria compreender as razões deste respeito. Não significa isto que, também na perspectiva teleológica, é necessário algo como uma "fundamentação"? Se quisermos ser rigorosos devemos responder pela negativa. Para que não haja confusão, seria talvez preferível falar de uma justificação. Dito isto, se se insiste no termo fundamentação, esta última terá de ser outra fundamentação que não a "absoluta” da deontologia.

O que se procura, neste caso, seria uma justificação do respeito do outro, e esta teria uma forma muito diferente da "fundamentação" procedimental e formal da deontologia moral. É uma tarefa deste tipo que tenta levar a cabo, na sua ética, o filósofo alemão Robert Spaemann. Tal como Ricœur, também Spaemann renuncia à via da "fundamentação última", na medida em que esta, segundo este autor, já pressupõe "a decisão de ser moral”. Esta decisão não pode ser justificada por uma racionalidade puramente "imanente". Contra aquilo a que Spaemann chama "redução kantiana da ética", ele considera que "o fundamento de toda e qualquer

igualmente analisados por Ricœur. Por uma questão de economia de espaço, no texto deste trabalho apenas referimos o exemplo, apesar de tudo menos complexo, do médico que, em casos graves, se encontra perante a opção de mentir ou dizer a verdade ao doente. 
decisão moral não é a exigência de imparcialidade [decorrente de uma lei impessoal e universal] mas a realidade do outro" 29 . O outro é sempre um singular. Sem a "percepção" desta "realidade" singular, a universalidade da lei que ordena a imparcialidade não teria sentido.

Um problema maior que coloca a ética de Spaemann vem do facto de esta "percepção da realidade do outro" não ser uma simples percepção sensível, mas a "consciência de um 'sagrado', de um incomensurável”. O que os nossos olhos vêem seria, assim, uma "imagem do incondicionado", imagem que não é simples simulacro mas fonte de uma "evidência metafísica”. Na base desta teoria da intersubjectividade está, portanto, uma teoria metafísica, ou até mesmo teológica, da imagem do supra-sensível, do "absoluto", do "sagrado", e, em última instância, de Deus. "Deus" é o nome próprio do singular que constitui o referente de última instância do "absoluto" ou do "sagrado". A partir desta metafísica da "imagem do incondicionado", Spaemann retira, entre outras, duas conclusões importantes. A primeira é que "não há ética sem metafísica"30. A segunda é que "contra o assassínio [Mord] só pode haver, em última instância, um argumento religioso"31. Este argumento seria o do carácter "sagrado" da subjectividade, a qual se fundaria numa experiência do sagrado tout court, ou seja do absoluto religioso ou de Deus.

Conclusões deste género pressupõem a fé. Isto não nos deve impedir, contudo, nos casos em que a fé religiosa não existe, de seguir a argumentação de Spaemann, enquanto filósofo, até um certo ponto. Até porque, como sugeria Nietzsche na passagem citada no início deste trabalho, não será talvez possível construir uma ética sem um elemento de crença. Só restará saber se esta tem de ser "religiosa”. Podemos, pois, começar por seguir Spaemann precisamente até ao ponto em que ele afirma que a "exigência de justiça [...] é fundada na evidência da realidade do outro"32. Merleau-Ponty, que se assume como filósofo não crente (no sentido religioso), não diz outra coisa quando escreve que "a percepção do outro já funda a moralidade" 33 .

Resta saber o que é a "percepção da realidade do outro" e como é que ela funda a moralidade. O percepcionado, neste caso, não poderá ser outra coisa senão o corpo, os gestos, as palavras do outro. A tarefa filosófica que aqui se anuncia consistiria na elaboração de uma teoria fenomenológica da percepção do outro, a qual ocuparia o lugar da metafisica da

\footnotetext{
29 Spaemann, 1998, 131.

30 Spaemann, 1998, 132.

31 Spaemann, 1998, 127.

32 Spaemann, 1998, 132.

33 Merleau-Ponty, 1946, 70.
} 
imagem que encontramos em Spaemann.

Por outro lado, para uma fenomenologia do outro não seria inútil o contributo da antropologia aristotélica, sem esquecer a sua doutrina da philia. Para Aristóteles, o cerne da realidade de cada ser humano - aquilo a que ele chamava o ergon do ser humano - é uma actividade. É energeia psychês kata logon ${ }^{34}$ - actividade pensante da psychê. Ora, esta actividade manifesta-se de muitas maneiras no visível - e tem sempre um lado visível. Segundo o próprio Aristóteles manifesta-se muito particularmente nos actos a que chama praxeis ${ }^{35}$, nas "acções" de interacção com outrem. Mas também se manifesta, podemos acrescentar, no mínimo gesto expressivo do corpo, na mínima palavra pronunciada. Não é, pois, necessário recorrer a uma metafísica da imagem ou do "sagrado" para pensar a "realidade do outro".

É verdade que isto ainda não explica a bondade do respeito do outro. Para isso poderá contribuir, até certo ponto, a teoria aristotélica da philia. Esta última permite resolver o paradoxo aparente de uma ética que, por um lado, dá como tarefa ao sujeito ético a busca da felicidade própria, a qual tem como condição o amor de si, a philautia, e, por outro lado, exige a esse mesmo sujeito que ame o outro pelo que ele é, e não por interesse material ou fonte de prazer, na medida em que ele é um "outro eu mesmo", um "alter ego". A solução do paradoxo está em que, no homem de bem, a sua felicidade forma uma unidade com a felicidade do outro ou dos outros.

\section{Notas finais}

À dupla questão incial: "o que é e para que serve a fundamentação da moral?” podem ser dados respostas de dois tipos, consoante se parta da ideia de uma "fundamentação absoluta" ou da ideia de uma outra "fundamentação", que poderá não ser mais que uma simples justificação motivacional, uma genealogia das razões, baseada na experiência do mundo e dos outros. No caso da "fundamentação última" ou absoluta, fundamentar consiste em demonstrar (inclusivamente por argumentos ad absurdum) uma necessidade lógica, uma não contradição interna - lógico-formal ou transcendental - imanente à própria estrutura da racionalidade. As críticas de Ricœur, Spaemann, Taylor e outros mostram que este procedimento falha o âmago do próprio fenómeno da moralidade, ou seja, dito de outro modo, tendem a afirmar que a "necessidade" moral não é uma necessidade lógica - quer esta seja pensada como necessidade "se-

\footnotetext{
34 EN, 1098a 7-8.

35 EN, 1098a 14.
} 
mântica” ou "pragmática”. A admitir a validade destas críticas, pode-se dizer, como resposta à segunda questão do título deste trabalho, que a fundamentação absoluta não serve para nada.

Isto não impede que, de um ponto de vista genealógico, possamos admitir que a tarefa da Letztbegründung corresponda a um desiderato da racionalidade moderna - e, como tal, "sirva" para alguma coisa do seu ponto de vista. Do ponto de vista de uma filosofia da modernidade tem interesse saber para que serve a fundamentação da moral. Podemos começar por dizer que a sua primeira função seria a de uma auto-confirmação ou auto-afirmação de uma razão moderna "nominalista", uma razão que, sabendo não ter acesso à "essência das coisas" se limita à estrutura formal das relations of ideas e à constatação dos factos relativos às matters of fact. Para lá da crítica habitual relativa ao "formalismo", iniciada por Hegel, importa sublinhar que esta "razão" passa ao lado da racionalidade prática. Por outro lado, numa segunda função, a fundamentação absoluta serviria para conferir à lei moral da razão prática a "necessidade" e a autoridade dos mandamentos do Deus monoteísta da teologia moral. A fundamentação vem legitimar a filosofia moral como herdeira da função da teologia moral ${ }^{36} \mathrm{e}$, ao mesmo tempo, provar a superioridade daquela em relação a esta. A fundamentação absoluta é a resposta ao famoso desafio de Diderot (retomado por Dostoievski): "s'il n'y a pas de Dieu tout est possible.” A fundamentação absoluta pretende fornecer a certeza absoluta que, mesmo se não houver Deus, nem tudo é possível ou permitido.

Aquilo que não deve ser possível é o Mal. Uma terceira função da fundamentação seria, assim, por conseguinte, como vimos em Ricœur, uma resposta ao problema do Mal. É compreensível que este problema exija uma resposta enérgica - o que a fundamentação absoluta pretende ser. Mas será uma tal resposta filosoficamente adequada? No contexto grego o mal moral, das duas uma, ou bem provém de um defeito da natureza - neste caso temos aquilo a que Aristóteles chama thêriotês, a "bestialidade", hoje em dia falaríamos de "psicopatia" ou de defeito "genético" - ou bem a uma insuficiente educação do desejo ou formação do carácter - e neste caso o "mal”, a acção moralmente má, deriva de uma akrasia, um descontrolo de que o sujeito - e/ou os seus educadores nunca é totalmente inocente. A problemática cristã da "liberdade", da fraqueza da "vontade livre" e do "pecado" veio dramatizar o problema do mal. A teologia protestante acentua esta dramatização - o que é bem visí-

36 É claro que esta filiação não é vista com bons olhos. De Schopenhauer a Elisabeth Anscombe, são numerosos os autores que criticam, como escreve Tugendhat, o facto de "a necessidade de dar à moral uma fundamentação absoluta [ser] um resíduo de uma moral religiosa”, Tugendhat, 1993, 97. 
vel na teoria kantiana do "mal radical”. Para esta teologia, neutralizar o mal imanente ao arbítrio não depende, em última instância, nem do sujeito nem da educação mas da "graça divina". É caso para dizer: para grandes males, grandes remédios. Isto poderá ser válido no plano teológico. Já no plano filosófico é muito duvidoso que o seja. Para refutar sem apelo as argúcias e astúcias de uma inteligência maligna ao serviço de inclinações impuras, uma actividade do intelecto que Kant descreve com o verbo vernunfteln, um termo altamente pejorativo, a fundamentação só poderia ser "absoluta" - ou não fundamentar coisa nenhuma.

Uma última justificação importante da fundamentação absoluta tem que ver com o "uso público da razão". Como dizia Hegel há quase dois séculos nas suas Lições de filosofia do Direito, "aquilo que nos nossos dias pretende à validade já não pode ser apenas válido por obra da violência, do hábito ou dos costumes, mas por evidências e razões." ${ }^{37}$ Neste sentido, a pretensão à validade universal e o formalismo jurídico e procedimental da fundamentação deontológica prestam-se particularmente bem à discussão pública, nomeadamente em contextos políticos ou de direitos fundamentais. A haver justificação de uma fundamentação "absoluta", esta constituiria, provavelmente, a mais plausível.

Acontece, porém, que as "razões" da fundamentação não são, nem têm de ser, absolutas ou últimas. Num sentido lato do termo podemos admitir uma fundamentação "fraca" que consistiria numa justificação motivacional da moralidade, de carácter fenomenológico ou hermenêutico. Esta última não produz, sem dúvida, certezas tão indubitáveis como a fundamentação lógico-transcendental, para além de conter, como Nietzsche já suspeitava, insuperáveis elementos de crença - a começar pela crença que quem está em face de mim é um "outro eu”, e a acabar na crença que a intenção de uma vida conseguida, a "visée éthique" de que fala Ricœur, não é realizável num mundo humano excessivamente marcado pela violência ou pela indignidade. A fundamentação "fraca" apresenta duas vantagens: a de permitir compreender com mais profundidade o fenómeno da moralidade, e, por isso mesmo, de ser mais motivadora do agir bem do que a fundamentação absoluta.

\section{Bibliografia}

ALBERT, Hans (1982), “Münchhausen oder der Zauber der Reflexion”, in Albert, H., Die Wissenschaft und die Fehlbarkeit der Vernunft, Tübingen, Mohr, pp. 58-94.

ALBERT, Hans (1992), Traktat über kritische Vernunft, Tübingen, Mohr.

${ }^{37}$ Hegel, 1986 [1821], 483. 
APEL, Karl-Otto (1996), "Diskursethik als Verantwortungsethik - eine post-metaphysische Transformation der Ethik Kants”, in Schönrich, Gerhard (org.), Kant in der Diskussion, Frankfurt, Suhrkamp.

HEGEL, G.W.F. (1986 [1821]) Grundlinien der Philosophie des Rechts, Frankfurt, Suhrkamp, 1986.

KANT, Immanuel (1965 [1785]), Grundlegung zur Metaphysik der Sitten, Hamburgo, Felix Meiner.

KRÄMER, Hans (1992), Integrative Ethik, Frankfurt, Suhrkamp.

MACINTYRE, Alasdair (1985), After Virtue. A Study in Moral Theory, Londres, Duckworth.

MERLEAU-PONTY, Maurice (1946), Le primat de la perception, Paris, Vrin, 1996.

NIETZSCHE, Friedrich (1988 [1886]), Jenseits von Gut und Böse, Kritische Studienausgabe (KSA), Vol. V, Berlim, Walter de Gruyter.

RICEUR, Paul (1990), Soi-même comme un autre, Paris, Éditions du Seuil.

SPAEMANN, Robert (1998), Glück und Wohlwollen. Versuch über Ethik, Estugarda, Klett-Cotta.

TAYLOR, Charles (1993), "The Motivation behind a Procedural Ethics", in Beiner, Ronald; Booth, William J. (eds.), Kant and the Political Philosophy. The Contemporary Legacy, Harvard University Press.

TUGENDHAT, Ernst (1994), Vorlesungen über Ethik, Frankfurt, Suhrkamp.

WILliAMS, Bernard (1985), Ethics and the Limits of Philosophy, Harvard University Press, Cambridge, Massachusetts.

\section{RESUMO}

Ponto de partida do artigo é a ideia de que a filosofia moral moderna está excessivamente centrada na questão da fundamentação absoluta da norma moral, o que contrasta com a ética antiga, virada para uma hermenêutica do bem e movida por motivações perfeccionistas do sujeito. Procede-se a uma análise crítica das razões deste esforço teórico de fundamentação. Uma razão essencial está no facto de a razão moderna interpretar a moralidade no sentido de uma pura racionalidade auto-referencial, ou seja como uma simples não-contradição. Não implicará a atitude moral, o "ser moral”, um elemento de "crença” (Nietzsche)? A partir desta questão é problematizada a adequação do ideal moderno (cartesiano) de “cientificidade” à racionalidade prática. Procede-se a uma análise crítica das fraquezas da mais recente versão de fundamentação, que se pretende “absoluta”, a de Karl-Otto Apel. São analisados, em seguida, projectos éticos de dois autores contemporâneos, Paul Ricœur e Robert Spaemann, que, apesar de afirmarem o "primado da ética” (Ricœur) de tipo teleológico, não prescindem de conferir algum sentido à questão, pós-cristã e moderna, da moralidade. A concluir, são avançados alguns elementos de resposta às questões enunciadas no título do artigo. 


\section{RÉSUMÉ}

La philosophie morale moderne est excessivement centrée sur le problème de la fondation absolue de la norme morale, ce qui contraste avec l'éthique ancienne, tournée vers une herméneutique du bien et mue para des motivations de perfectionnement éthique du sujet. On commence par développer une analyse critique des raisons de cet effort théorique de fondation. Une raison centrale tient au fait que la raison moderne interprète la moralité dans le sens d'une pure rationalité auto-référentielle, c'est-à-dire d'une simple non-contradiction. L'attitude morale, le fait d'être moral, n'implique-t-elle pas, au contraire, une « croyance " (Nietzsche)? L'adéquation de l'idéal moderne (cartésien) de « scientificité » à la rationalité pratique est problématisée à partir de cette question. Cela mène à une analyse critique des faiblesses de la plus récente entreprise de fondation, prétendument « absolue », de la norme morale, celle de Karl-Otto Apel. Sont analysés, ensuite, les projets éthiques de deux auteurs contemporains, Paul Ricœur e Robert Spaemann, qui, même s’ils affirment le " primat de l'éthique » (téléologique) sur la morale, essaient de donner un sens à la question post-chrétienne et moderne de la moralité. En conclusion sont énoncés, à partir des analyses développées, quelques éléments de réponse aux questions posées dans le titre de l'article. 